\title{
A transgressão estrutural do pensamento de Artaud
}

\section{VERA LÚCIA FELICIO}

O dialogismo do carnaval

Se partirmos da definição de "estrutura carnavalesca" dada por Kristeva, em seu texto: "Recherches pour une Sémanalyse", segundo a qual: "A estrutura carnavalesca é como a marca (trace) de uma cosmogonia que não conhece a substância, a causa, a identidade fora da relação com o todo que só existe na e pela relação" ${ }^{1}$ a cena do Teatro da Crueldade, que é a escrita de Artaud, faz reviver esta cosmogonia carnavalesca antiteológica que se apresenta como um jogo. Sendo o carnaval essencialmente "dialógico", isto é, constituído estruturalmente por relações, distâncias, analogias e oposições não-exclusivas, este jogo significante é, não somente uma atividade, mas um significado. Aquele que participa do carnaval é, ao mesmo tempo, ator e espectador, perdendo sua consciência enquanto pessoa, passando pela cena carnavalesca, desdobrando-se em sujeito do espetáculo e objeto do jogo. Nesta festa, o sujeito é negado; o autor aparece como anonimato que cria e se vê criar enquanto homem e enquanto máscara, como ego e como outro. $\vec{E}$ esta estrutura carnavalesca do Teatro da Crueldade que reencontra o Dionisismo de Nietzsche no espaço dialógico, porque mata o Deus-Uno-Logocêntrico.

A figura de Dionísios, ligada ao êxtase e ao terror, à selvageria e ao repouso, exprime a própria estrutura dialógica de seu ser contra-

(1) Cf. Kristeva, Julia, "Recherches pour une Sémanalyse", in Essais, Collection Tel Quel, Editions du Seuil, 1969, p. 160. 
ditório. Deus da embriaguez portador da alegria, todavia, é também voltado para a morte e para o sofrimento. A exigência desmedida de Dionísios em relação à entrega por parte daquele que o segue é acompanhada de uma posse pelo deus em relação a seu seguidor mortal, que implica a quebra dos valores tradicionais. As Bacantes são levadas ao delírio, numa orgia de loucura, arrebatadas por Dionísios, o deus da contradição trágica, exultante e alegre, sofredor e moribundo, dilacerado pelo conflito interno. Dionísios ri de todas as ordens e de todas as regras; riso que precede, paradoxalmente, o silêncio da morte. $\mathrm{E}$ é assim que o riso do carnaval, dionisíaco, não é simplesmente paródico; não é mais cômico do que trágico, mas, ambos: tragi-cômico. E é neste sentido que a cena dionisíaco-carnavalesca do Teatro da Crueldade não é a da lei nem a de sua paródia, mas, seu outro; a cena da escrita artaudiana é o espaço de um assassinato (do Logos Ocidental, do Deus-Uno, do Pai) e revolução (transgressão do dado, sujeito tornado processo, re-jeição).

O carnaval exterioriza a estrutura da produtividade literária refletida, colocando a nu seu inconsciente: o sexo e a morte, que Artaud considerava ligados às "forças negras" que o Teatro da Crueldade elucidaria. O que caracteriza a estrutura da cena do Teatro da Crueldade, a estrutura carnavalesca e o ritual dionisíaco, e que os aproxima, é a estrutura dialógica que os atravessa; isto é, as oposições não-exclusivas que se constituem como conjuntos vazios ou somas disjuntivas, contestando as leis da linguagem, assim como Deus, a Autoridade e a Lei social. É neste sentido que o pensamento dialógico é essencialmente rebelde e subversivo.

No Teatro da Crueldade, onde não há mais lugar para a díade: ator/espectador, cena/sala, a cena do carnaval liga-se à Vida, ao jogo e ao sonho, tornando-se um espaço mágico, no qual a linguagem pode escapar à linearidade (à lei), e tornar-se o único lugar em que se realiza a "infinidade potencial" do discurso, onde o proibido fala através da linguagem da transgressão, celebrando o sonho, o corpo, a cena, o dialógico.

A linguagem rejeita sua função de representação, provocando o riso, questionando a onipotência do conceito e do poder absoluto do pensamento discursivo. E é porque Kristeva considera o aparecimento do sexo e da morte na linguagem como exploração da mesma, consagrando a "ambivalência" e o vício, que poderá afirmar que há, na estrutura dialógica da linguagem, uma luta contra o Cristianismo e sua representação. A estrutura carnavalesca enquanto cena do Teatro da Crueldade é o que desloca a lei, transgride a língua, quebra os valores 
estabelecidos, sendo, por isso, assassina e revolucionária, no sentido de uma transformação radical da Existência.

Se retomarmos a tragédia dos "Cenci" de Artaud, observaremos que esta peça pretende-se emancipar dos valores pressupostos como "legítimos" pela tradição; o tema do incesto é abordado de modo amoral, não se distinguindo mais vícios e virtudes, destruindo a unidade épica do homem, bem como sua crença no princípio de identidade e na lei da causalidade. A lógica da peça é tecida de contradições; a linguagem parece fascinada pelo "duplo" e pelas oposições não-exclusivas. A cena do Teatro da Crueldade passa a se constituir como exploração do corpo, do sonho e da linguagem, espacializando os conflitos políticos e ideológicos do momento histórico vivido. Assim sendo, a estrutura dialógica da cena carnavalesca do Teatro da Crueldade é a transgressão cênica, atual, por um lado, da luta contra o idealismo e a metafísica do Deus-Uno, e, por outro lado, luta contra o realismo mecanicista. O que o Teatro da Crueldade propõe é a rejeição dos pontos fixos, seja do idealismo, seja do realismo, constituindo-se como atividade social e política da época que discute com a teologia, a lei e a razão formalista. Se o Teatro da Crueldade é atual, isto se faz porque é estruturado como uma ambivalência, um "polemos" ou uma estrutura de oposições não-exclusivas que abrem o sujeito artaudiano para a produção de seu espaço próprio, enquanto linguagem-cênica em processo.

Artaud se faz linguagem cênica, escrita hieroglífica, onde o que conta não é mais a vida individual, mas este aspecto da vida mais originário, em que a oposição dos princípios é o fundo no qual o homem está mergulhado. O Teatro da Crueldade não é catártico no sentido aristotélico, mas um ato político, cuja única mensagem a ser transmitida é a de cada um tornar-se ele mesmo na "eterna alegria do devir". Não há mais o monologismo de um princípio teológico (homem-deus), nem sentido único ou verdade transcendente. Se a linguagem hieroglífica do Teatro da Crueldade é rigorosa, comparável à linguagem matemática, este rigor provém de sua própria organização espacial codificada, e nunca como reflexo ou representação de um texto ou de um universo previamente existentes a si própria; sua estrutura faz compreender-se a partir dela mesma, sem nenhuma verdade transcendente a ser refletida; o significado emerge da própria materialidade do significante que o gera em seu processo. A linguagem do Teatro da Crueldade não conhece nem lei, nem hierarquia entre seus componentes; é assim que a palavra alinhar-se-á entre os demais elementos cênicos e terá o mesmo peso que os demais, e valor semelhante ao que as palavras têm nos sonhos. 
A estrutura dialógica do carnaval e da cena do Teatro da Crueldade traduz uma lógica de relação e de analogia, e não de substância e de inferência, opondo-se, por isso mesmo, por um lado, à lógica aristotélica, e, por outro lado, à lógica formal contemporânea, contradizendo-a em função de outras formas polifônicas de pensamento, onde a "ambigüidade" se faz presente na estruturação e constituição do poético.

\section{A heterogeneidade do sentido}

Se a comunidade depende de uma medida comum para existir, sua base é a linguagem; e é assim que, para Kristeva: "A política revolucionária, quando não é uma repetição, deveria ser o tempo em que a política (a medida comum, portanto, a linguagem) quebra-se". ${ }^{2}$ Deixando de lado a política dos lingüistas que se fecham na estrutura ou no sistema da linguagem, na Mathesis, Kristeva volta-se, no texto supracitado, para os lapsos de linguagem, os jogos de palavras, o riso e a metáfora, que testemunham alguns desarranjos da estrutura que, apesar de se refazer, carrega a marca (trace) de uma "heterogeneidade". E se o estruturalista deseja esquematizar esta heterogeneidade e o teórico da gramática gerativa recusa-a, Kristeva pretende reativá-la, através do que denomina de "Semiótico", entendido como uma modalidade de significação diferente do "Simbólico". Enquanto este último se liga, na ordem da linguagem, ao signo, isto é, ao que pertence ao nível da nominação, da sintaxe e da denotação de um objeto ou de umá "verdade" científica, o primeiro, o Semiótico, é cronologicamente anterior ao signo e sincronicamente transversal ao mesmo, à sintaxe, à denotação e à significação. O Semiótico é compreendido como uma articulação provisória, um ritmo não-expressivo, um elemento que distingue, aparecendo no discurso adulto como: não-sentido do sentido, ritmo, jogo de palavras, prosódia, riso, grito. Não possui unidades significativas, contradizendo-se com o Simbólico. Ora, se a linguagem é uma prática, ela o é na medida em que o Simbólico e o sentido, conjuntamente, são deslocados pelo Semiótico. É este papel revolucionário do Semiótico que Artaud traduz, heterogêneo ao sentido, desorganizando, pelo Teatro da Crueldade, este mesmo sentido tético codificado; sendo, por este motivo, que ele compara o público do Teatro da Crueldade a alguém que vai ao dentista sofrer uma cirurgia dentária, não podendo sair de lá intacto, ou, comparando o Teatro da Crueldade ao fenômeno

(2) Kristeva, Julia, Psychanalyse et Politique, Editions du Seuil, 1974, p. 62. 
da peste, que desarranja todos os órgãos, terminando por matar o indivíduo, sem provocar lesões aparentes. O que importa não é a estrutura, mas, pelo contrário, nesta perspectiva, ela é apenas um momento efêmero de um processo de revolução da linguaguem, em que todo enunciado lingüístico deveria ser uma contradição heterogênea entre o "tético" comunicável e o ritmo Semiótico específico. E esta transgressão tornada prática de linguagem que Artaud propõe, através do Semiótico; seu Teatro é grito; sua poesia cênica nasce do "caos que se organiza"; sua revolução é o ato pelo qual o Simbólico se esvazia diante do ritmo que provoca e desorganiza o sentido, fazendo-o ruir, transformando-o. E é assim que o texto-loucura de Artaud é recusado por uma política que prega a medida comum; seu Teatro da Crueldade, ao re-pensar o vazio, o processo, a prática, coloca em cheque a ordem, o sistema e o poder da lei no Estado. Artaud re-vive o sujeito em processo pelo Teatro da Crueldade, e, por isso mesmo, é marginalizado pela ordem vigente. E nesta função revolucionária une-se a Mallarmé, Rimbaud, Lautréamont, Joyce, Kafka... porque, ao subverterem, seja o código ideológico através da crítica às instituições, seja o código da língua, última garantia da unidade do sujeito, estes autores falam a mesma linguagem.

Esta "subversão" de Artaud que é uma prática e não uma evasão, pois não formula uma nova linguagem apenas estruturalmente acabada ou plena de sentido, gritando pela revolução, mas, ainda falando a mesma linguagem do opressor, é o que permite apontar para a radicalidade do aspecto revolucionário de Artaud, enquanto seu teatro é imediatamente o suporte de um ritmo semiótico, em que o corpo se desdobra, sendo sujeito e objeto concomitantemente. Segundo Kristeva, "o fascismo é o retorno do reprimido no monologismo religioso ou político". ${ }^{3}$ E é este monologismo que Artaud recusa, em função do semiótico pulsional, heterogêneo ao sentido e ao Uno, voltando-se para o eterno deslocamento de pontos fixos.

O rigor matemático da cena do Teatro da Crueldade não pode, pois, ser reduzido ao puro estruturalismo; pelo contrário, a revolução de Artaud liga-se à dissolução da estrutura, no ponto de estouro do par sujeito/objeto, natureza/cultura, pelo ritmo "insensato" do pré-verbal, constituído pelo Semiótico. É é por isso que Kristeva pode afirmar que: "O sujeito de uma nova prática só pode ser o sujeito de uma nova prática discursiva". ${ }^{4}$

(3) Kristeva, Julia, Psychanalyse et Politique, p. 66.

(4) Kristeva, Julia, Psychanalyse et Politique, p. 69. 
O processo de significação, proveniente das pulsões e operações semióticas pré-verbais, logicamente anteriores à linguagem, deixa de lado o "Sujeito Unário", que se define, para Kristeva, como "o sujeito que se institui desta censura de ordem social". ${ }^{5}$ Nem o sujeito-filho, contido no esquema edipiano, nem o sujeito da ciência, reduzido a objeto de estudo, mas o "sujeito em processo". Através dos "abortos", "síncopes" e "expectorações" na linguagem, Artaud desorganiza o sistema lingüístico, fazendo emergir suas puilsões tornadas gestualidade no Teatro da Crueldade, constituindo, através de seu corpo, sua "fragmentação" existencial, investindo no "lugar móvel" do processo feito linguagem. Este processo é a-familiar, a-filial e a-social, promovendo revoluções através de uma ação social deste processo de rejeições. O Teatro da Crueldade pede um público constituído por "sujeitos em processo" que participarão, pelo "transe coletivo", da mesma teia que os entrelaça no gesto que é negatividade, porque é abertura in-definida; o sujeito heterogêneo é unidade impossível, não porque esteja perdido, mas multiplicado. O "sujeito em processo" atravessa o quadro lingüístico e dele se serve para indicar como uma "anáfora" (gesto cuja função é a de designar a pluralidade, dé-signer, assinalar, desenhar, como o fazem os Tarahumaras que apontam, quando eles contam), ou um hieróglifo, na medida em que o real jamais é colocado previamente, mas emerge continuamente do processo pulsional.

A alegria dionisíaca da criação na destruição se dá como transgressão das regras na e pela linguagem pulsional do corpo de Artaud, no Teatro da Crueldade, tornada musicalidade poética, dança. Este ritmo semiótico, fluxo que re-jeita, é fonte de "prazer estético". O corpo agitado de Artaud, um belo pèse-nerfs, testemunha o estouro da unidade e a passagem das pulsões. E na figura de Heliogábalo, o "anarquista coroado", figura bi-sexual e hermafrodita que expressa o "dialogismo" e os "opostos não-exclusivos", que se apresenta a unidade feita de contrários inconciliáveis. Esta mobilidade do corpo do homem-teatro que é Artaud, na prática da dança e do gesto, volume teatral que esposa a mobilidade e a resistência no vaivém entre a Vida e a cena, torna-se passagem para fora do sentido, miragem do não-sentido através do sentido que deslancha o riso dionisíaco da lucidez.

Se a revolução de Artaud tem um sentido atual, não o é devido à assimilação de regras, pois estas não existem como imposição, mas porque sua única proposta é a de pensar a arte ligada à Vida, transgressão perpétua do sentido.

(5) Kristeva, Julia, "Le Sujet en Procès", in Artaud, Col. 10/18, Union Générale d'Êditions, 1973, p. 44. 